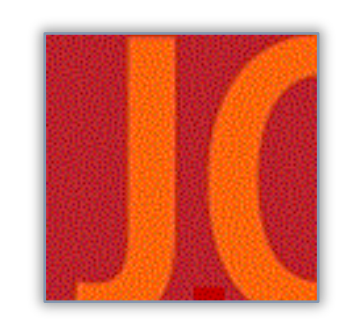

\title{
Walking as Attunement: Being With/In Nature as Currere
}

\author{
Ellyn Lyle, Yorkville University \\ Celeste Snowber, Simon Fraser University
}

\begin{abstract}
Being physically and spiritually attuned to the world around us forms the loom on which we weave our curricular understandings. Here, we strive to find the extraordinary in the ordinary and make room for a poetic way of attending to the lived curriculum. More than a way of doing research, we regard this way of being as a deep and disciplined presence with/in the world we inhabit. Through our own individual practices of walking the earth, our physicality explores the relationships between flesh and stone, and rain and tears, and the immediacy of the poetic takes form. Our walking practices open up the space not only to mindfulness, but bodyfulness, where the present moment has the capacity for the infinite. This type of active contemplation invites us into an expansive place where we can consider the very nature of education and its potential to foster or impede holistic teaching, learning, living, and being. Through writing together, we lift ourselves and each other out of the metaphorical and literal containment of our current contexts and find an invitation to walk and write into wonder.
\end{abstract}

Keywords: currere; walking pedagogy; poetic inquiry; relationality 


\section{Marcher comme harmonie : être avec/dans la nature en tant que « currere "}

\section{Résumé :}

Être physiquement et spirituellement en phase avec le monde qui nous entoure constitue le métier sur lequel nous tissons nos compréhensions curriculaires. Ici, nous nous efforçons de trouver l'extraordinaire dans l'ordinaire et de faire place à une manière poétique d'assister au curriculum vécu. Plus qu'une manière de faire de la recherche, nous considérons cette manière d'être comme une présence profonde et disciplinée avec/dans le monde où nous vivons. À travers nos propres pratiques individuelles de marcher sur la terre, notre réalité physique explore les relations entre le chair et la pierre, et la pluie et les larmes, et l'immédiateté de la poétique prend forme. Nos pratiques de marche ouvrent l'espace non seulement à la pleine conscience, mais aussi au corps, où le moment présent a la capacité de l'infini. Ce type de contemplation active nous invite dans un lieu expansif où nous pouvons considérer la nature même de l'éducation et son potentiel pour favoriser ou empêcher l'enseignement, l'apprentissage, la vie et l'être holistiques. En écrivant ensemble, nous nous élevons et nous sortons les uns les autres du confinement métaphorique et littéral de nos contextes actuels et trouvons une invitation à marcher et à écrire dans l'émerveillement.

Mots clés : le currere; la pédagogie de la marche; l'enquête poétique; le relationnel 
Every day I walk out into the world to be dazzled, then to be reflective.

(Oliver, 2003, p. 65)

\section{Walking Together Apart}

$\mathcal{W}$ e come to this writing as long-time students of place. Being forged through the margins between Land and Sea, we continue to be recreated. There are lessons that can only be fashioned by the tide, an ebb and flow that mark our personal, professional, and writing lives. When place is so much a part of you, there is always a longing present for the particularities of smells, sounds, and sights that inhabit our sensory knowing. As writers and wanderers, we have been gifted with walking into the wonder of each other's places through our collective writing. In each other's absence, we have found presence-the presence of shared understanding of how the lived curriculum of Sea, Wind, Shore, and Land have (trans)formed us. As we write this piece, we are 8000 kilometers apart from each other, yet, the gap closes as we individually and collectively walk into each other's landscapes and words.

Ellyn

There is an essence of place that extends beyond character, history or inhabitants; something elemental, inherent-an alchemy awaiting. I say alchemy deliberately, as I think of Paulo Coelho's The A/chemist (1988), a wonderfully pregnant novella that first nudged me into thinking about my essential self in relation with the soul of the world. When this book was published, I was 23 and too young to name many of the important nuances introduced within its pages. I'd like to say that more than two decades wiser, I have grown sage-like, but I am inclined to admit I have become increasingly conscious of my limitations. Two things emerged, though, in this literary relationship: my certainty that place has its own soul or spirit, just as I imagine people do; and my longstanding belief that our soulmates might be places, rather than people. 


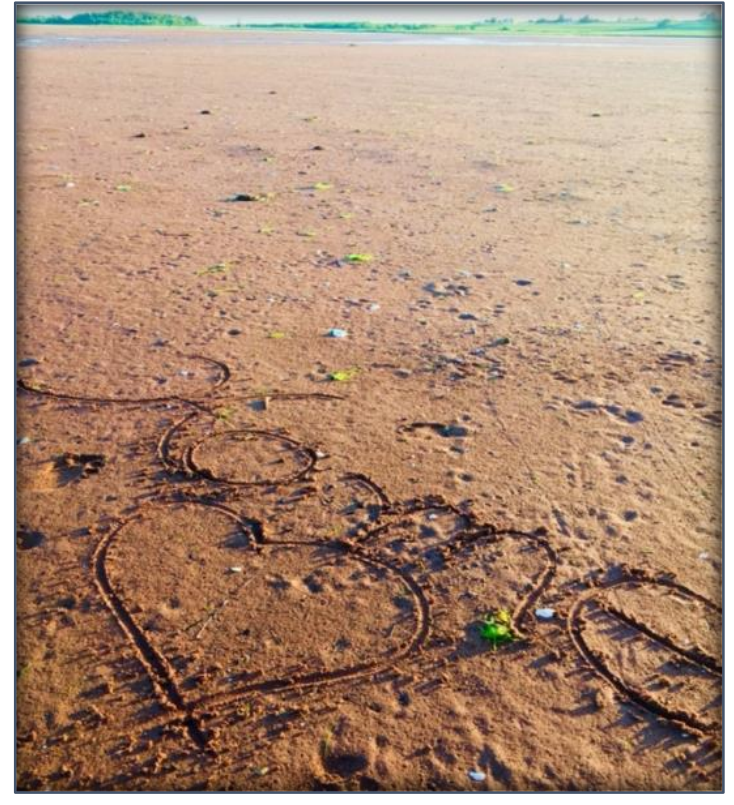

Genius Loci. (Photo credit: Ellyn Lyle)
Some say home is not a place so much as a feeling we carry in our hearts but either my feelings are too big or my heart is too small because I cannot carry with me all I feel here.

Soaking up the expanse of land and water and spirit I reconnect with every version of myself that I have ever been and all those me's I've not yet grown into.

I wonder once again about the red thread of fate and if my soul connection is to place, rather than person.

\section{Celeste}

I have often thought of how place informs me as walking the path as the path walks me. Place is deep inside my embodied knowing; the smell of the sea, mud on my worn feet, and salt in the air, are written in my sense of home. I am an island girl, having grown up in a peninsula town in Nahant, on the North Shore of Massachusetts, where daily activity included watching the tides, traipsing on the black rocks, and diving in the cold ocean. Walking on the coast of rocky shores grounded me, the crooked paths laced in seaweed and blue mussels, while lobster buoys floated in the distance. I was anchored to the sea, and the sea was within me, just as surely as human beings are made up of water. I am no longer close to the rough Atlantic, as I now live closer to the Salish Sea of the Pacific, and now walking paths in proximity to rivers and creeks are my daily sustenance. There are places which form us - that get inside us and become our teachers. As I walk various paths, I continue to listen to the nuance of things and wait for their lessons. 


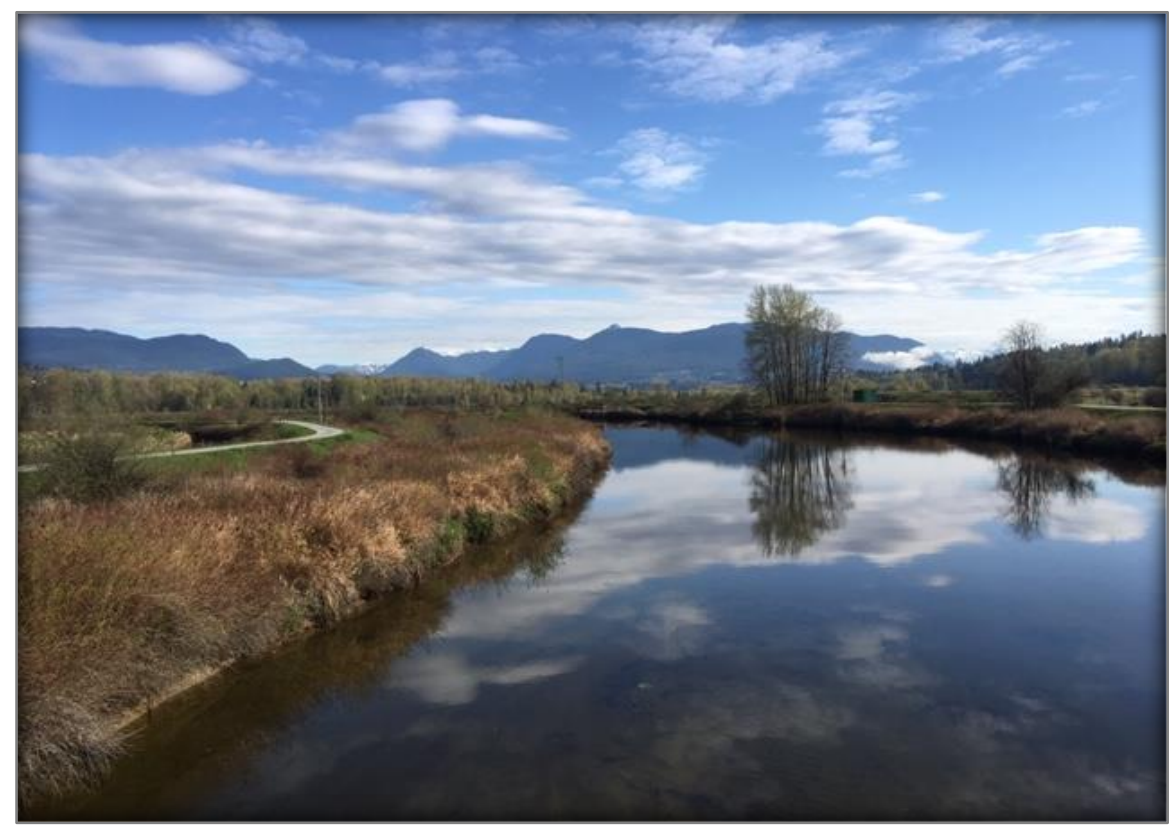

What the River Knows. (Photo credit: Celeste Snowber)

Ellyn

I understand the wisdom which lies in waiting with grace, patience, and gratitude. My early years were spent at The Shore, a three-acre parcel of land nestled along the banks of Malpeque Bay and situated on a small island in the Gulf of St. Lawrence. The Shore became the first and forever curriculum of my life. There, I became a student of place as I learned to navigate the ambiguous margins between land and water. I learned from the Land that, while we reap what we sow, the quality of the harvest is the result of both good practices and good fortune. I learned from the Bay the beauty of erasure - the wonder of beginning each day anew, the marks of the previous day wiped clean. Although it was much later before I could articulate how the places we dwell also dwell in us, I recognise now that The Shore was as integral to my development as my family or formal education. I took its lessons with me as I went out into the world, first for hours or days, but eventually for years at a time. Even now, as I sit some 5200 kilometres away on my terrace in Hamburg, Germany, the ocean between us does nothing to diminish our enduring relationship. Here, in my temporary home, the rustle of the wind through the centuries-old trees, bowed by time and war and perseverance, transports me home where I feel the salty breezes flirt with the trees in their ancient courtship. In this movement between two worlds-my heart-home and my wohnort-I pause to consider the paths that have led me here, even as I anticipate the journeys that lay ahead. I am enveloped by a sense of gratitude as I recognise two things in the same moment: that my first and forever place in the world taught me an abiding presence that both guides and sustains me; and that it continues to orient me (Roberts, 1998) as I wander to new places in search of fresh fields of study in my living curriculum. 
The long-known

deeply held bouquet

suffuses the air

courting my senses and

seducing me

desolation is conquered

by the promise of renewal

as the white shackles melt

and give way to

red resplendence.

the breezes lusciously ripe

with salt air and sunlit kisses

transform the land

to a mellow richness

punctuated by clover

potato blossoms

and hope.

not to be upstaged,

the canola fields

outshine the sun

even as the barley waltzes.

together - ancient and elegant

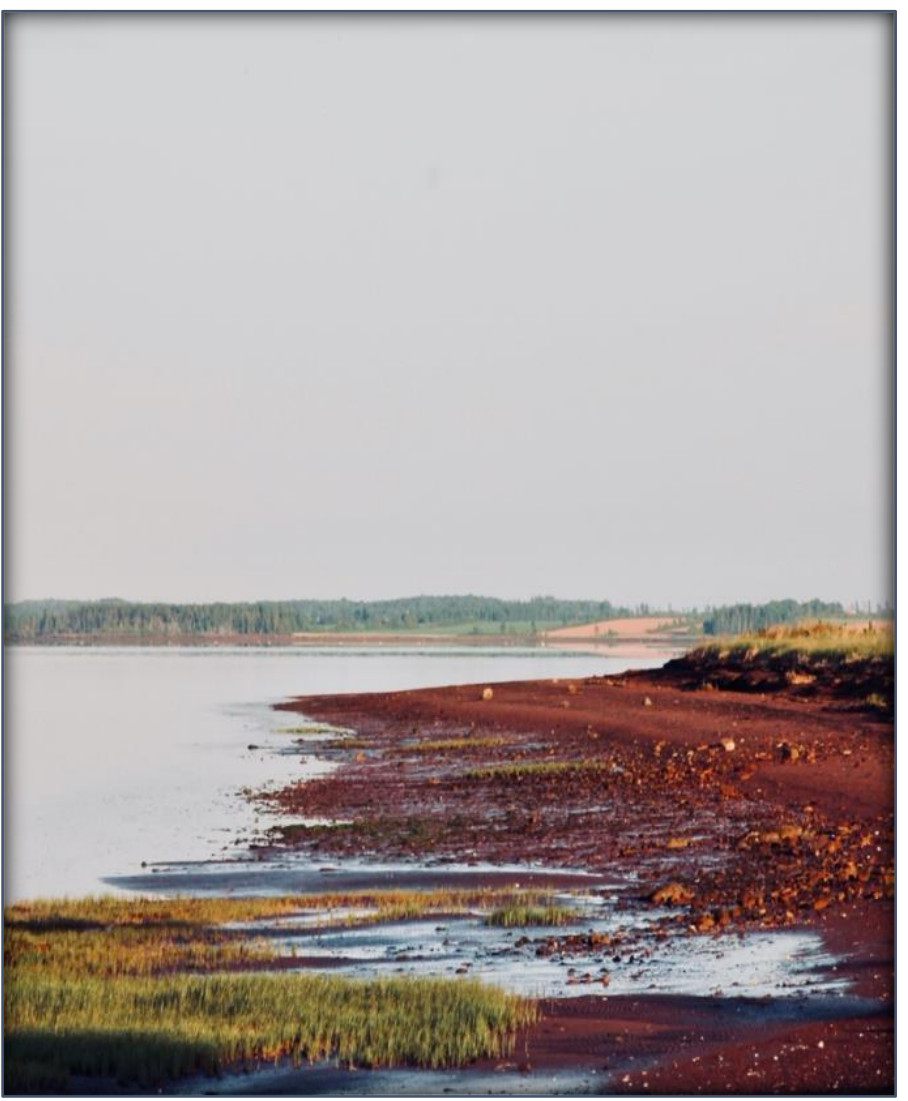

Vanishing Point. (Photo credit: Ellyn Lyle)

they captivate

with a choreography that lingers.

Enraptured,

I am filled

to every corridor of my soul.

\section{Celeste}

As you recall the sensory journey of walking along your treasured shoreline, my feet feel the gravel path beneath me to the sounds of the Fraser River in my neighbourhood. This is another shoreline, so different than my beloved walks on my island town on the Atlantic, or my walks on the Shoreline Trail of the Burrard Inlet near the Salish Sea. The river is high in this moment as I walk, swelling and rushing as it surfaces debris, logs and branches. Occasionally, crows and gulls sit on these remnants, which need nothing for passage: the river takes full responsibility for carrying the wooden remains through its waterways. There is no other trajectory for them; the broken logs, once trees, are in river's magnificent current.

The river has been a companion to me these last years as I have ruminated at its edge, walking every opening in every public space I can access. They all have names, these public spacesSapperton Landing Park, New Westminster Quay Boardwalk, Westminster Pier Park, Burnaby Fraser 
Foreshore Park —all hugging the notorious Fraser River. All these names are inadequate, though, and I much prefer the Indigenous name for the river, which, in the Halqemeylem language, is Sto:lo.

The Sto:lo River teaches me one lesson over and over again: be and stay in the flow of your own rhythm. Let the river of your own destiny take you. We cannot push the river nor our own destinies. Many years ago, I was on a train in Portugal, traveling from Lisbon to Sintra, a town located on the Portuguese Riviera. The conductor took my ticket and said, "You have the wrong destiny." I'm sure he meant to say I had the wrong destination, but I have never forgotten this exchange. What does it mean to be in the river of our own destiny? What does it feel like to be in the flow of our own lives?

I know what it means to push. I know what it means to walk with the wind and against it. As I turn this over in my mind, I keep walking to the river's edge in afternoon light and eventually find perch on some rocks. I observe what the river carries, even as it propels me to reverie. Tugboats pull structures, herons and crows dance in the sky, and swallows flicker in between all the creatures of the heights. Walking is what transports me. I surrender to my body's gravity in each step, where I am invited into the fertility of the place where land meets water. The river becomes my spiritual director, guiding me to a course on being, a watercourse that teaches me to cooperate with my own nature. These are all small pockets of beauty and small miracles.

\section{What if there are miracles}

What if there are miracles beneath the soles of your forgotten path twigs, branches, moss, and mist waiting for your attention to say yes to what calls you

Listen to the earth's knowing one which tenderizes the tyranny of busy Watch the lily pads' faces greet water through floating creating an aesthetics of place oxygenating from their roots

Here is a model for sustenance providing shelter for fish where light and dark meet in a hidden curriculum

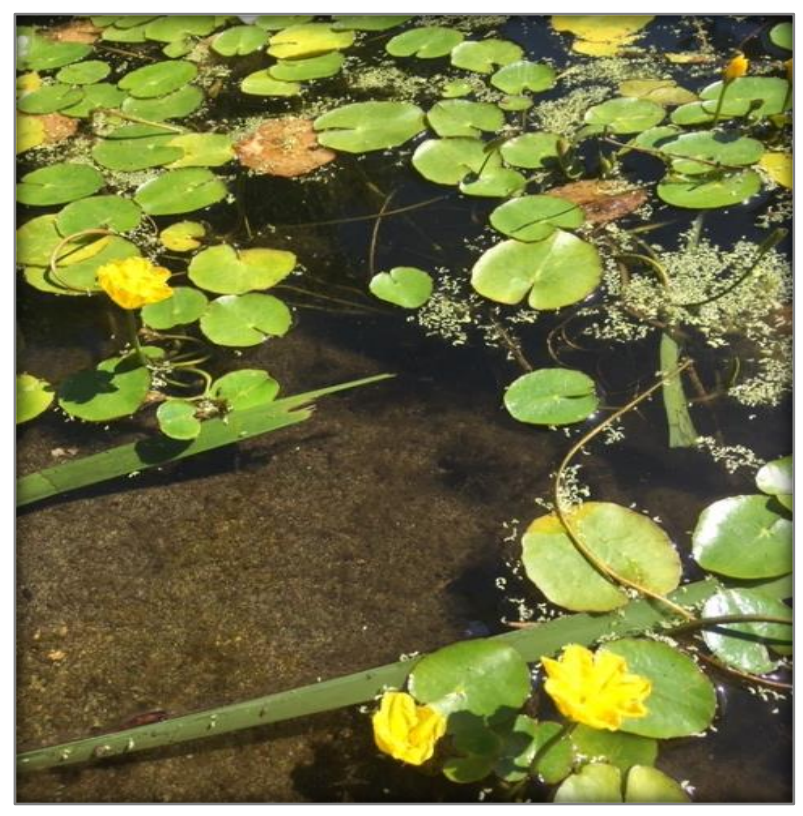

Lily Pad Wisdom. (Photo credit: Celeste Snowber)

Give yourself the same

a refuge for pondering

all in a morning walk 
Ellyn

I appreciate how our wandering the vanishing point between Land and Water has evoked a consideration of the Sky. I could not have imagined as a child that I would wander so far from the place I first called home, nor could I have anticipated that the many years and meandering paths, which have created physical distance, would only strengthen my connection to it. From my current place, I often turn my eye to the Sky to narrow the gap between here and home. My memory calls up the scent of salt air and newly harvested potatoes and fills me with such profound joy and longing that I wonder how I keep from bursting. This is part of the wonder of a heart-home: like a loving parent or inspiring teacher, it fosters a curiosity and courage that allows me to wander and learn at large. While it remains at the other end of that red thread of fate that irrevocably unites us, it propels me forward with the confidence born of knowing I am also safely anchored. Baldwin et al. (2013) say that place matters because it grounds us while encouraging new ways of being in the world. They, like Parker Palmer (1998) and David Gruenewald (2003), remind me that we are shaped by the places we inhabit, and how we are shaped is largely contingent upon the quality of attention we give those places and ourselves in relation to them. I have nurtured such attentiveness until it grew into a deliberate presence, which stirred something in my deepest self that can only be described as spiritual attunement. This way of being began as a child when I lay in the long grass under the canvas of the Sky as she wrote and rewrote messages for me and me alone.

\section{puffs of exhaust \\ spun of pink cotton candy \\ atop a base of indigo \\ with an infusion of colour \\ at its core - \\ like a dollop of marmalade \\ dropped into a blueberry \\ custard \\ the ethereal and everchanging \\ Sky.}

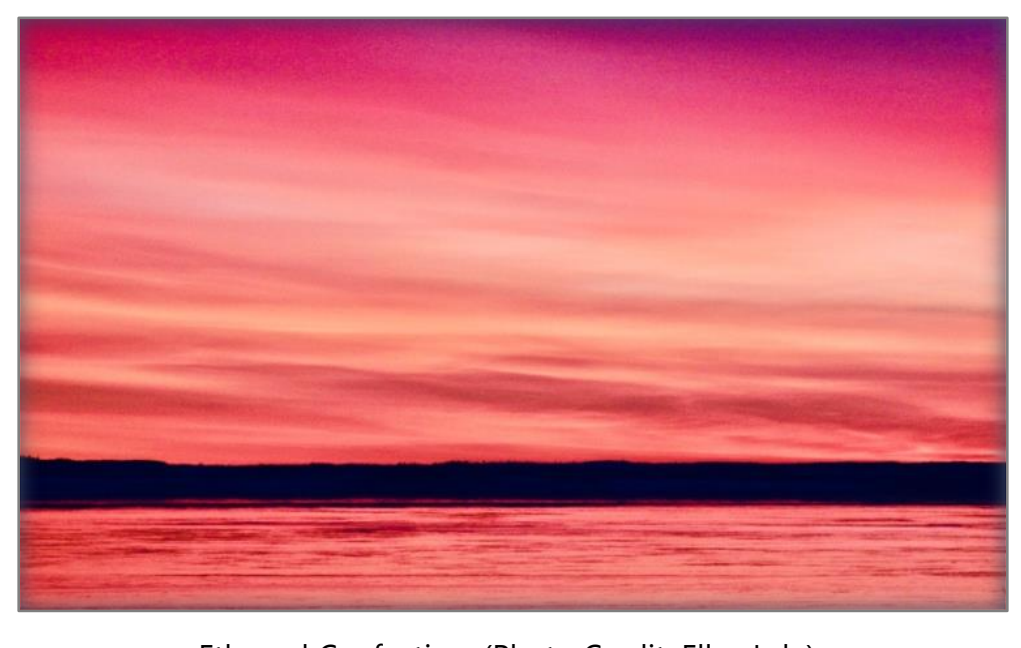

Ethereal Confection. (Photo Credit: Ellyn Lyle)

Such experiences taught me that what we see is always changing, not only because the subject shifts but also because of our own dynamic metamorphosis. In this way, the Sky was my first introduction to critical reflexivity. She taught me that wherever we travel, there we are-unchanged and never the same. She also taught me that such movement is a magnificent teacher. Perhaps that's another reason I look to place as my living curriculum-because it uses the local as a starting point to overcome often hegemonic and ubiquitous educational agendas developed elsewhere 
(Bartholomaeus, 2013; Judson, 2015). In this way, it privileges lived experience as the curricular vehicle to transport us to deeper understandings of both regional and global affairs (Israel, 2012; Sobel, 2004). Such an approach encourages teachers and students to be active participants in meaning making, rather than mere consumers of other people's truths. Moving between the local and the global also helps us to understand that we are visitors in every place we encounter, regardless of how deep or sustained the relationship. This realisation was impossible for me to attain while cocooned at The Shore, certain that I was as much a part of the landscape as the iron-rich soil. It took leaving my nested existence to understand that, while I might feel like I belong there, it does not and could not ever belong to me.

no man is an island

but i am no man

islands are about knowing our boundaries without being limited by them and pursuing change

even as we resist it

islands are about pretending certainty while embracing ambiguity

we are the illusion of constancy

and the reality of transience

islands want to belong

even as they marginalize

we are a celebration of self

even as we struggle to overcome it

despite how we resist being eroded by it we remain intimately connected to the very water that threatens us

islands are a special kind of contradiction but they endure.

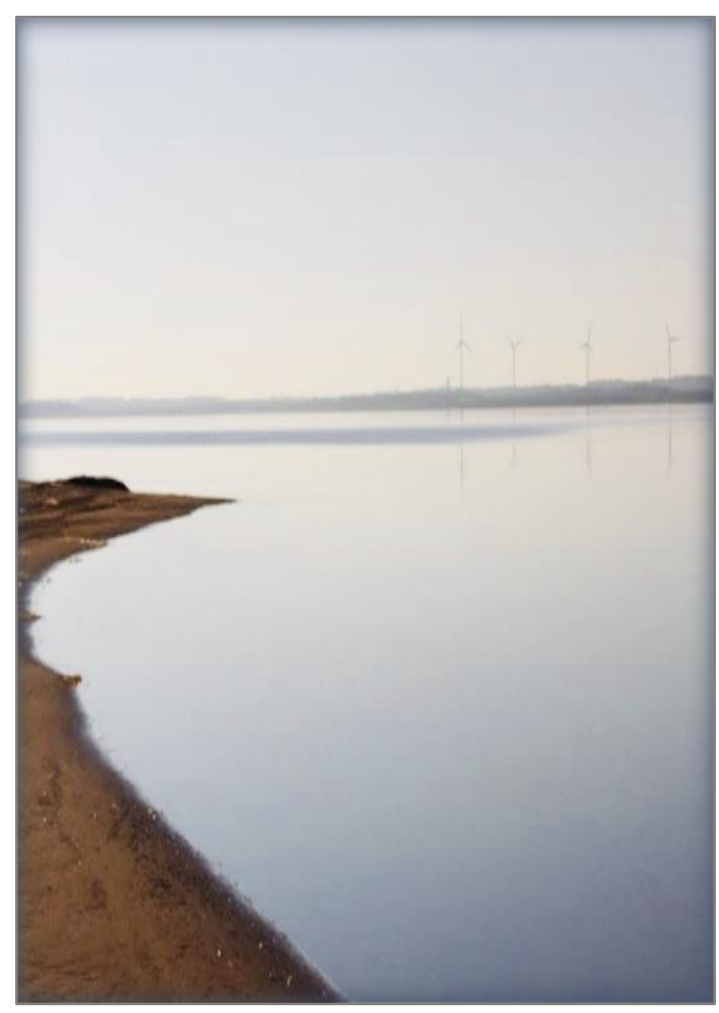

no man is an island. (Photo credit: Ellyn Lyle)

\section{Celeste}

Endurance-I have had a morning walking practice that has endured for almost three decades. Over the years, it has become my place of emptying, reflecting, praying, pondering, and creating. Poems, books, dances, and essays have been born in the insights from my walks, sojourns that have ushered me toward knowledge of my own physicality and spirituality. Intricately and intimately woven into my research and artistic creation, here, I empty and listen. Listen to the flight of the heron. Listen to my own tears. Listen to the words forming a new thought or insight. All of this listening is learning how to be in attunement with the natural world. The inner and outer landscape forge a unique connection where knowledge becomes intimate. There is an intimacy in this kind of 
creation, a place-based ecology formed in decades of writing, site-specific performances, and embodied ways of inquiry (see Snowber, 2014, 2016, 2018). I am fortunate to work within arts-based methodologies as they provide the opportunity to forge connections to bodily knowing and learning and honour somatic practices of walking and dancing that can uncover new ways of perceiving and understanding. This way of being takes me back to flow and the influence of Csíkszentmihályi's theories, which advocate for us to find the optimal psychological state of deep engagement, concentration, and focus that supports heightened learning (see Csíkszentmihályi, 1996, 1998). Our collective walks, and those enjoyed in solitude, become the entrance to a sense of flow that opens up a place for spaciousness and fertile creativity.

I continue to harness courage from the history of other walkers and writers. William Wordsworth, in his prolific writing career, was known to have walked 175,000 miles. Taneda, the Japanese haiku poet, was famous for combining walking and writing. He says, "talentless and incompetent as I am, there are two things I can do, and two things only: walk, with my own two feet; compose, composing my poems" (Taneda, 2003, p. 9; with translation by B. Watson). I, like many other writers, find that walking is part of my writing. To walk is to access ancient knowledge and, increasingly, curriculum scholars are making poignant connections between walking and ways of being and thinking (Hotton, 2015; Irwin \& Lasczik, 2018, 2006; Springgay \& Truman, 2017). I return over and over again to experience the fabric of creation from the outside in and the inside out. I concur with you, Ellyn, that soulmates might be places and a deep invitation to experience not only mindfulness, but bodyfulness. Here can be the embodied, lived curriculum, which encompasses the mental, emotional, physical, and spiritual components of what it means to be human.

Ellyn

As I consider what it means to be human in the context of these places that welcome us, I wander and wonder about the very shaping of our personhoods. Walking together apart, we are learning to attend to the nuances of the places we inhabit. In so attending, we are finding ourselves returning to curriculum theory that invites us to newly consider lived experience. Drawing on Pinar's currere (1994), and his later notions of self-shattering and emancipatory reaggregation (2010), we assume that each day begins anew, albeit with a reflexive consciousness that encourages us to learn from yesterday as we recreate ourselves today. We hold the physical places that open us to being deeply meditative because they bring us closer to a state of divine grace. 
neither tentative nor frenzied,

it simply washes away

and nourishes

a counterbalance

to a fiery disposition

(alas, I am an Aries)

it gives freely

without expectation of reciprocity

It simply is.

There are lessons here for me

A life lived in

unassuming generosity - in sustenance-

in gratitude for the ability to contribute

is its own abundance

inspiring such moments of consciousness

with/in these places that hold us

in spiritual lushness.

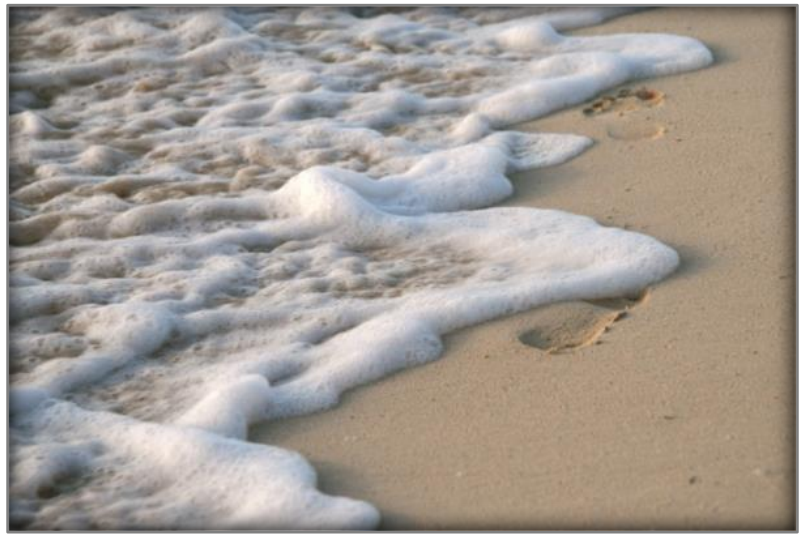

Neither Time nor Tide. (Photo credit: Ellyn Lyle)

\section{Celeste}

When you allude to wandering toward spiritual lushness, I think of sauntering because it allows us to pause and, in that pause, we are cracked open to grace. In these spaces, time shifts and extends, creating the capacity to attune with place; here is a somatic approach to being present. Many philosophers and writers have contemplated the connection to the power of walking. Thoreau is known to have spent at least four hours a day sauntering through the woods, hills and fields, in order to preserve his health and buoy his spirits. Thoreau was not juggling parenthood and working, as many scholars and poets today, so four hours of walking was possible for him in ways it might not be for others; nonetheless, the relationship between attending to creation, writing and cultivating insights was clearly connected to sauntering. I love the etymology of saunter, which implies to muse. Walking, sauntering and moving are all ways to grow the muse and nourish a creative way of being in the world. The muse is connected to flow, and she lets the breath and blood move through our hands, thighs, hips and heart, walking the paths before us. 


\section{Saunter}

I have sauntered through passages at your edge ribbed stones, craggy rocks. forged in moisture

I too hydrate precipitation of tears release in my gait

The pocket in my sacrum sheds the last lines of stress held from the juncture of not knowing what might come Purged by wind off the shore in a land where too many voices diminish souls yearning

Iopen in increments

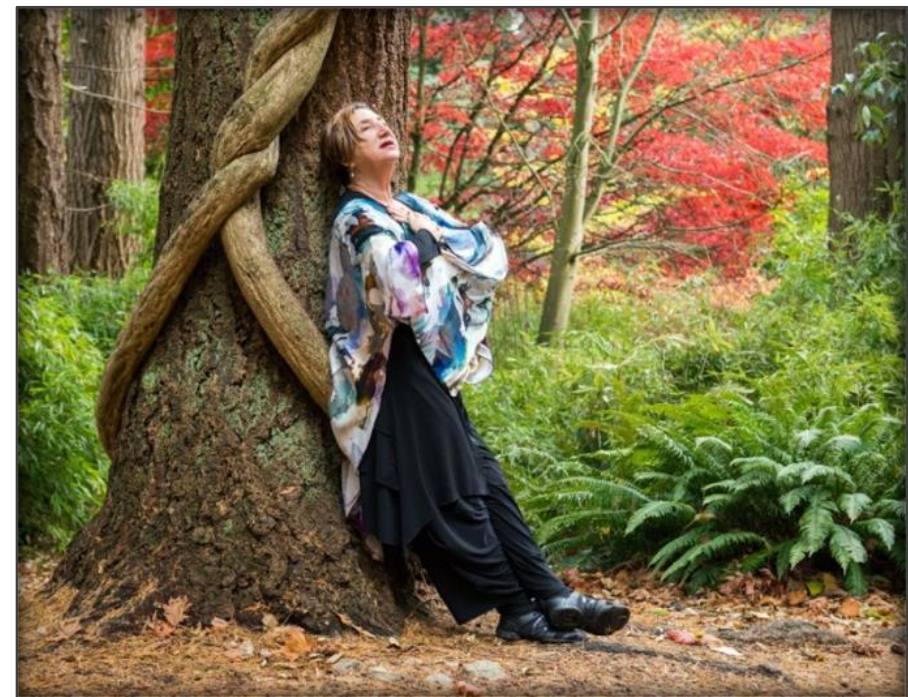

Tree Intelligence. (Photo credit: Chris Randle) to what my body

has always known.

\section{Ellyn and Celeste}

Accepting that we are visitors in the places we wander has helped us to "walk in a good way" (Tait, 2016, p. 21), treading lightly within the curriculum as terrain. Having wandered in teaching, learning, or living across dozens of countries now, we have relished this opportunity to walk together apart while we consider attunement. In this time of frequent and forced containment, there is opportunity to become intimate with our current contexts and ourselves in them. We feel pinched, lately, by the inability to travel, but we think about the movement of the water adjacent to the Lands that hold us and the birds in the skies that watch over us, and we become enraptured by birdsong. We find wonder in the nuances of their gifts of tweets, vocalized in trills and cackles, pecks, buzzes, and beats. After all, "what is birdsong, but truth in rehearsal" (Williams, 2012, p. 49). 


\section{A wild landscape}

You don't need to travel thousands of miles to access the wild place within and beyond open up the windows of your hips and home let spiritus rush through salt and sweat river, mud, and winds of your body's terrain.

Dance in the rain and tears of your heart wander in what rushes through your veins know here is a wild landscape attune to sighs, softness and silences. A thousand epiphanies wait at your toes be curious in your own becoming draw near to the infinite.

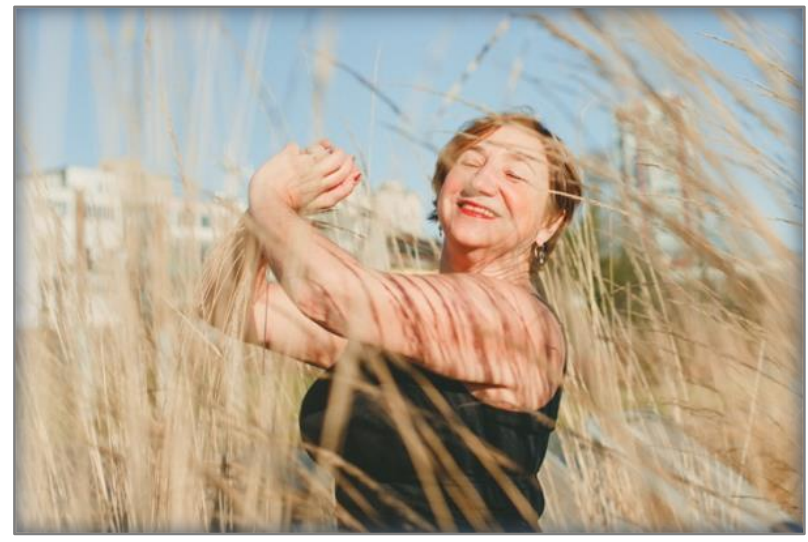

Draw Near to the Infinite. (Photo credit: Michele Mateus)

Write out of the mundane

mud, magic and mystery

traverse from blood to ink

wear gestures as accessories.

Know your muse

is waiting for you

in the pause;

the great ripening.

\section{About the Authors}

Ellyn Lyle is an avid reader of life and lived experience. Intensely interested in creating spaces for learners to engage meaningfully with their studies, she is drawn to inquiries that seek to overcome compartmentalized, fragmented or dehumanized approaches to education. Having joined the academic community full time in 2011 , she is currently Dean in the Faculty of Education. The use of critical and reflexive methodologies shape explorations within the following areas: intersections of self and subject and their implications for teacher and learner identity; praxis and practitioner development; lived and living curriculum; and undivided ways of knowing and being. Find out more about her work at https://yorkvilleu.academia.edu/EllynLyle

Celeste Snowber is a dancer, writer and award-winning educator who is a professor in the Faculty of Education at Simon Fraser University. She has published widely in the area of arts-based research and her books include Embodied Inquiry: Writing, Living and Being Through the Body, as well as two collections of poetry. Her latest book of poetry, The Marrow of Longing, explores her connection to her Armenian identity. Celeste continues to create site-specific performances in the natural world between land and sea. Find out more about her work at www.celestesnowber.com or https://www.sfu.ca/education/faculty-profiles/csnowber.html 


\section{References}

Baldwin, L., Block, T., Cooke, L., Crawford, I., Kim, N., Ratsoy, G., \& Waldichuk, T. (2013). Affective teaching: The place of place in interdisciplinary teaching. Transformative Dialogues: Teaching \& Learning Journal, 6(3), 1-20. https://journals.kpu.ca/index.php/td/article/view/1321

Ball, E. L., \& Lai, A. (2006). Place-based pedagogy for the arts and humanities. Pedagogy, 6(2), 261287. http://doi.org:10.1215/15314200-2005-004

Bartholomaeus, P. (2013). Place-based education and the Australian curriculum. Literacy Learning: The Middle Years, 21(3), 17-23.

Coelho, P. (1993). The alchemist. Harper Torch.

Csíkszentmihályi, M. (1996). Flow and the psychology of discovery and invention. Harper Collins.

Csíkszentmihályi, M. (1998). Flow: The psychology of optimal experience. Harper Perennial.

Gruenewald, D. A. (2003). Foundations of place: A multidisciplinary framework for place-conscious education. American Educational Research Journal, 40(3), 619-654. https://doi.org/10.3102/ 00028312040003619

Hotton, V. (2015). Walking practices in higher education: An inquiry into the teaching, writing and walking practices of five contemporary academics [Unpublished doctoral dissertation]. Simon Fraser University.

Irwin, R. (2006). Walking to create an aesthetic and spiritual currere. Visual Arts Research, 32(1), 75-82. https:///doi.org/10.4324/9781315467016-12

Israel, A. L. (2012). Putting geography education into place: What geography educators can learn from place-based education, and vice versa. Journal of Geography, 111(2), 76-81. https://doi.org/10.1080/00221341.2011.583264

Judson, G. (2015). Supporting ecological understanding through in-depth and imaginative study of a place-based topic or issue. Canadian Journal of Environmental Education, 20, 139-153. https://cjee.lakeheadu.ca/article/view/1352

Lasczik Cutcher, A. J. (2018). Moving-with \& moving-through homelands, languages \& memory: An arts-based walkography. Sense.

Lyle, E. (2020). Contemplating how the places we dwell, dwell in us. In E. Lyle (Ed.), Identity landscapes: Contemplating place and the construction of self(pp. 1-13). Brill/Sense.

Oliver, M. (2003). Owls and other fantasies: Poems and essays. Beacon Press.

Palmer, P. (2017). The courage to teach (20th ed.). Jossey-Bass. (First published in 1998)

Pinar, W. F. (1994). Autobiography, politics and sexuality: Essays in curriculum theory 1972-1992. Peter Lang.

Pinar, W. F. (2010). Notes on a blue guitar. Journal of Educational Controversy, 5(1), 1-9. https://cedar.wwu.edu/jec/vol5/iss1/18/

Roberts, E. J. (1998). Place and the human spirit. The Humanistic Psychologist, 26(1-3), 5-35. https://doi.org/10.1080/08873267.1998.9976964 
Snowber, C. (2014). Dancing on the breath of limbs: Embodied inquiry as a place of opening. In A. Williamson, G. Bateson, S. Whatley, \& R. Weber (Eds.), Dance, somatics, and spiritualities: Contemporary sacred narratives (pp. 115-130). University of Chicago Press.

Snowber, C. (2016). Embodied inquiry: Writing, living, and being through the body. Sense.

Snowber, C. (2018). Embodied perspectives on creativity. In C. Mullen, (Ed.), Creativity under duress in education? Resistive theories, practices, and actions (pp. 201-214). Springer.

Sobel, D. (2004). Place-based education: Connecting classrooms and communities. Orion Society.

Springgay, S., \& Truman, S. E. (2017). A Transmaterial approach to walking methodologies: Embodiment, affect and sonic performance. Body and Society, 3(4), 27-58. https://doi.org/10.1177/1357034X17732626

Tait, L. (2016). A scattered people. In J. Latremouille, A. Bell, M. Krahn, Z. Kasamali, L. Tait, \& D. Donald (Authors), kistikwânihk êsko kitêhk: Storying holistic understandings in education. Journal of the Canadian Association for Curriculum Studies, 14(1), 8-22.

Taneda, S. (2003). For all my walking: Free-verse haiku of Taneda Santouka with excerpts from his diary (B. Watson, Trans.). Columbia University Press.

Williams, T. T. (2012). When women were birds: Fifty-four variations on voice. Farrar, Straus \& Giroux. 